\title{
Oxygen isotope composition in extant shark teeth as a proxy to temperature reconstructions
}

ZIVILE ZIGAITE ${ }^{1}$, MARTIN WHITEHOUSE ${ }^{2}$, CARLOS OLIVEIRA $^{1}$, IVAN J SANSOM ${ }^{3}$, MATTHEW COWEN ${ }^{1}$ AND PER ERIK AHLBERG ${ }^{1}$

${ }^{1}$ Uppsala University

${ }^{2}$ Swedish Museum of Natural History

${ }^{3}$ University of Birmingham

Presenting Author: zivile.zigaite@gmail.com

Oxygen isotopes are widely used as a climatic and oceanographic proxy, since the discoveries of vertebrate bioapatite's ability to record oxygen isotope composition of ambient seawater [1]. However, some "vital effects" on the $\delta^{18} \mathrm{O}_{\mathrm{P}}$ composition of the aquatic vertebrate apatite have been reported previously $[2,3]$. The purpose of our work is to explore any such impacts via detailed evaluation of stable oxygen isotope ratios $\left({ }^{18} \mathrm{O} /{ }^{16} \mathrm{O}\right)$ in the teeth of several species of extant sharks.

We have analysed $\delta^{18} \mathrm{O}$ compositions in-situ, the teeth sections were prepared in the Laboratory of Isotope Geology at the Natural History Museum of Stockholm (Sweden). The $\delta^{18} \mathrm{O}$ ratios were measured at the NordSIM facility, using secondary ionization mass spectrometry (SIMS). Data treatment was followed by statistical analysis.

Results show significant $\delta^{18} \mathrm{O}$ differences at inter-tissue level, as well as the impact of chemical pre-treatment on the final $\delta^{18} \mathrm{O}$ values. No significant inter-taxon variability was observed among the studied shark species.

[1] Kolodny et al. (1983) Earth Planet. Sci. Lett. 64, 398-404. [2] Pucéat et al. (2010) Earth Planet. Sci. Lett. 298, 135-142 [3] Žigaitė \& Whitehouse (2014) GFF 136, 337-340. 